\title{
Population genetic analysis of White Park Cattle in Germany
}

\author{
GÜNTER BIEDERMANN ${ }^{1}$, WERNER HECHT ${ }^{2}$, EIKE FANDREY ${ }^{3}$, HEIKE RUDOLPH ${ }^{3}$ and KAI \\ FRÖLICH ${ }^{3}$
}

'Witzenhausen; former: Department of Animal Breeding, University of Kassel, Germany, ${ }^{2}$ Department of VeterinaryPathology, Justus-Liebig-University Gießen, Gießen, Germany, ${ }^{3}$ Arche Warder, Zentrum für alte Haus- und Nutztierrassen e. V., Warder, Germany

\section{Abstract}

The population of White Park Cattle in Germany is composed of 11 males and 33 females. This group of cattle has been analysed with regards to generation intervals, coancestry, and inbreeding on the basis of three generations of ancestors. The average interval between the current and the parental generation amounts to seven years. The average coefficient of coancestry in the population is estimated to be $18 \%$ and the average degree of inbreeding at $16 \%$. The rate of inbreeding in the last generation is approximately $12 \%$. These values exceed those reported for most breeds of production animals.

Keywords: White Park Cattle, generation interval, relationship, inbreeding, rate of inbreeding

\section{Zusammenfassung}

\section{Populationsgenetische Analyse der White Park Cattle-Population in Deutschland}

Die aus 11 männlichen und 33 weiblichen Tieren bestehende White Park Cattle-Population in Deutschland wurde auf der Basis von drei Vorfahrengenerationen hinsichtlich ihrer Generationsintervalle sowie der Verwandtschafts- und Inzuchtverhältnisse untersucht. Das durchschnittliche Generationsintervall zwischen der aktuellen und ihrer Elterngeneration beträgt annähernd sieben Jahre. Der mittlere Verwandtschaftskoeffizient wurde mit 18\%, der mittlere Inzuchtkoeffizient mit 16\% geschätzt. Mit der aktuellen Generation stieg die Inzucht um ca. $12 \%$ an. Diese Werte liegen weit über jenen, die von anderen Nutztierrassen bekannt sind.

Schlüsselwörter: White Park Cattle, Generationsintervall, Verwandschaft, Inzucht, Inzuchtkoeffizient

\section{Introduction}

White Park Cattle are a horned cattle breed which is white with coloured points including the ears, nose, rims of eyes, teats, and feet. The intensity of these markings varies from herd to herd. White Park Cattle are considered primarily a beef breed and selected for this purpose. Sometimes they have also been kept for dual purposes, because some herds 
have been used for milk production. They are reported to be well adapted to nonintensive production systems (Ancient White Park Cattle Society of North America 2008). However, the primary aim of breeding and keeping of this endangered breed is to conserve a very ancient genetic resource.

These animals of medium size are known to be easily satisfied, robust, long living, easily calving and late maturing. Adult cattle are weighing about $400-500 \mathrm{~kg}$ (cows) and $600-700 \mathrm{~kg}$ (bulls), respectively, and reach a withers height of about $130 \mathrm{~cm}$ (cows) and $137 \mathrm{~cm}$ (bulls), respectively (ANONYMOUS 2008).

The origin of the White Park Cattle is rather obscure; their blood-group alleles seem to be unique among cattle breeds of Western Europe (CHILLINGHAM CATTLE ASSOCIATION 2000). The earliest references to the White Park type are found in the pre-Christian Irish epics in which white cattle with coloured points were often mentioned as a special breed. With the arrival of the Romans the Druids and their herds were pushed to the northern and western fringes of Britain and Ireland. It is in these areas that the ancient herds of White Park Cattle in the pre-sixteenth century were found, although none remain in Ireland (ALDERSON 2008). Living as a free-ranging population and being hunted as game animals they once covered the British isles before several herds were enclosed within various large parks in the thirteenth, fourteenth and fifteenth centuries by the nobility, mostly serving as game animals. The Dynevor herd originating in the time before 1200 is probably the oldest of these herds. The origin of the Chartley and Chillingham herd in England and the Cadzow herd in Scotland can be traced back to the middle of the thirteenth century (ALDERSON 2008).

At the beginning of the nineteenth century still more than a dozen of White Park Cattle herds existed. Only six of these herds survived, namely, those of Dynevor, Woburn, Whipshade, and Cadzow which are domestic herds, and those of Chillingham and Vaynol, which have survived as semi-feral herds.

The genetic data bank of EAAP (European Association for Animal Production) reported the number of White Park Cattle in the United Kingdom in 1997 as 31 bulls and 367 cows. The Ancient White Park Cattle Society of North America estimated a worldwide population of approximately 500 purebred females in 79 herds, plus bulls and young stock. The current status of the breed is regarded as critical (TGRDEU 2001)

Over the past 50 years, White Park Cattle have been exported to the United States of America, Denmark, Australia, Canada and Germany where new herds have been established.

In Germany the largest herd exists in the zoological garden of Arche Warder in Schleswig-Holstein in northern Germany; additionally, there are some smaller herds.

\section{Material and methods}

For the analysis of the White Park population in Germany the data (name, herd book number, date of birth, date of exit of the probands and all their ancestors) of 44 animals (11 males, 33 females) from four herds (number of October 2008) were available.

The program OPTI-MATE 3.85 of WREDE and SCHMIDT (2004) was used. As it is based on the pedigree method, the calculations had to be limited to only three generations of ancestors, because the data of elder generations are very incomplete. 


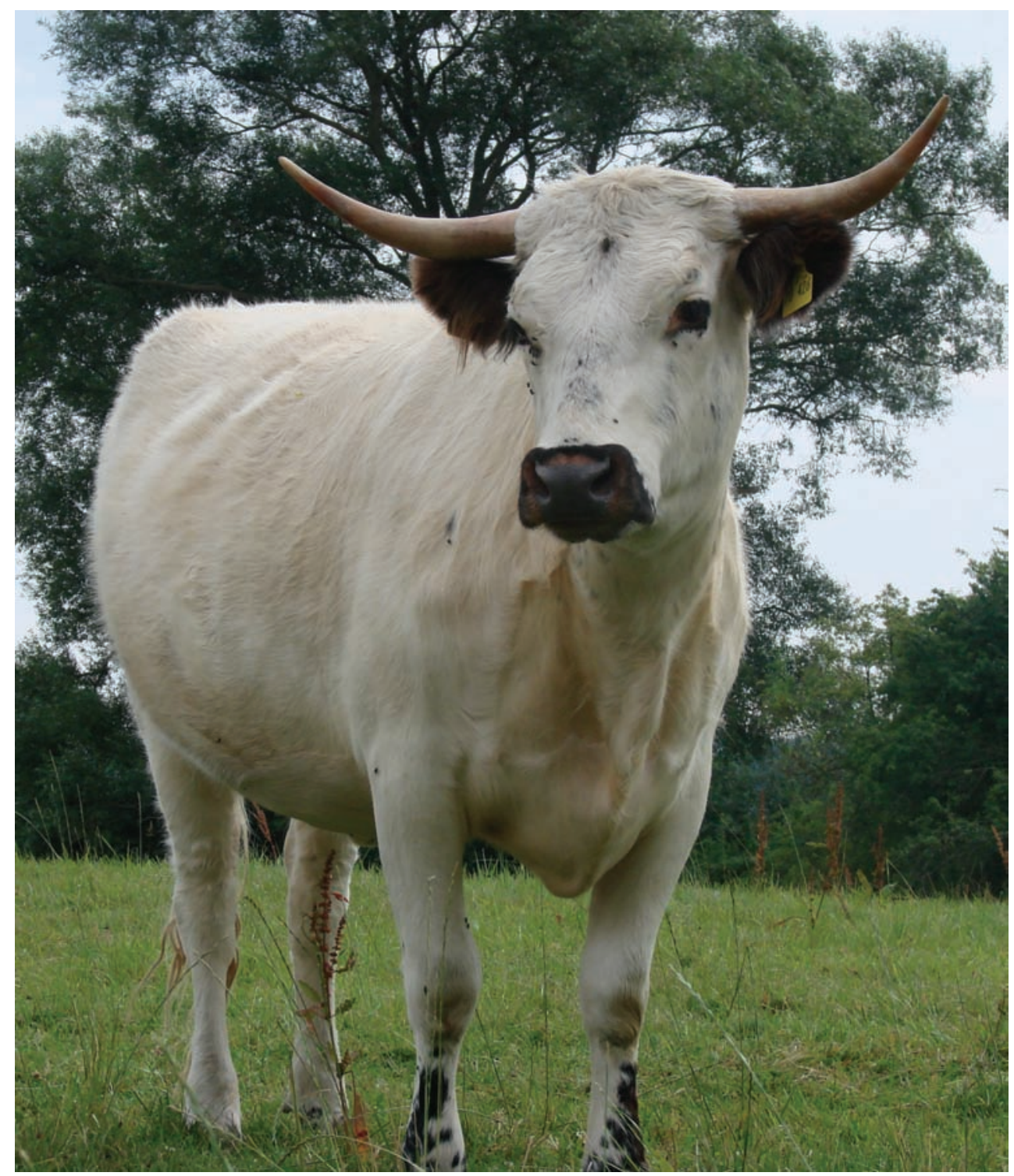

Figure 1

White Park Cow (Arche Warder - Zentrum für alte Haus- und Nutztierrassen e. V., Warder, Germany), Photo: Heike Rudolph

White Park Kuh (Arche Warder - Zentrum für alte Haus- und Nutztierrassen e. V., Warder, Deutschland), Foto: Heike Rudolph 
The date of birth of the animals and of their ancestors was necessary to calculate intervals between generations, which means the average age of parents when giving birth to their offspring used for future breeding. The contribution $G I_{i}$ of an animal / to the mean generation interval of a population can be estimated by the following equation:

$$
G l_{i}=\frac{\sum_{j=1}^{k} t_{i j} \cdot n_{i j}}{\sum_{j=1}^{k} n_{i j}}
$$

where is $n_{i j}$ the number of offspring of the $i$-th animal at the $j$-th birth, $t_{i j}$ the age of the $i$ th animal at the $j$-th birth and $k$ the number of births of the $i$-th animal.

The average generation interval $\mathrm{Gl}$ of the population results from the mean of all tested breeding animals:

$$
G l=\frac{\sum_{i=1}^{N} G I_{i}}{N}
$$

where is $N$ the number of breeding animals in the population.

The coefficients of coancestry and inbreeding of the individuals have been estimated utilizing the pedigree method created by WRIGHT (1923).

The coefficient of coancestry $R_{x y}$, as a measure of the degree of relationship, represents the probability that two randomly choosen alleles at any locus in two individuals $(X, Y)$ are identical by descent. It can be estimated as follows:

$$
R_{X Y}=\frac{\sum_{i=1}^{n}\left[\left(\frac{1}{2}\right)^{n_{i}+n_{2_{i}}} \cdot\left(1+F_{A_{i}}\right)\right]}{\sqrt{\left(1+F_{X}\right) \cdot\left(1+F_{Y}\right)}}
$$

where is $n_{1_{i}}$ the number of generations between $X$ and the common ancestor $A_{i}, n_{2_{i}}$ the number of generations between $Y$ and the common ancestor $A_{i}, F_{A_{i}}$ the coefficient of inbreeding of the common ancestor $A_{i}, F_{X}$ the coefficient of inbreeding of $X$, and $F_{Y}$ the coefficient of inbreeding of $Y$.

The mean of all coefficients of coancestry gives the average degree of relationship $\bar{R}$ in the population. Coefficients of coancestry vary between 0 and 1 or $0 \%$ and $100 \%$.

The inbreeding of an animal $X$ is measured by the coefficient of inbreeding. It represents the probability that both alleles at any gene locus are identical by descent. Of course, inbreeding requires the kinship of both parents. Coefficients of inbreeding are estimated by the following equation:

$$
F_{X}=\sum_{i=1}^{n}\left[\left(\frac{1}{2}\right)^{n_{i}+n_{z_{i}}+1} \cdot\left(1+F_{A_{i}}\right)\right]
$$

where is $n_{1_{i}}$ the number of generations between $X$ and the common ancestor $A_{i}, n_{2_{i}}$ the number of generations between $Y$ and the common ancestor $A_{i}$ and $F_{A_{i}}$ the coefficient of inbreeding of the common ancestor $A_{i}$. 
The mean of the coefficients of inbreeding of all animals in the population corresponds to the average coefficient of inbreeding $\bar{F}$ of the population. Coefficients of inbreeding vary between 0 and 1 or $0 \%$ and $100 \%$.

Using the pedigree method, incomplete pedigrees result in incorrect estimates of the coefficients of inbreeding. To minimize this underestimation the coefficients of inbreeding have been corrected by an index of completeness CI (SCHMIDT 2000), which gives the possibility to quantify the undervaluation of inbreeding independent of the number of unknown ancestors. All unknown ancestors, their position in the pedigree, and the distribution of the known male and female ancestors on the father's and mother's side of the pedigrees are considered:

$$
C l=\frac{\left(C_{\text {pat. } m} \cdot C_{\text {mat. } m}\right)+\left(C_{\text {pat. }} \cdot C_{\text {mat. } f}\right)}{2}
$$

where is $C_{\text {pat.m/pat.f }}$ the completeness of the male/female ancestors on the father's side and $C_{\text {mat.m/mat. }}$ the completeness of the male/female ancestors on the mother's side.

As there are no female ancestors in the first paternal generation and no male ancestors in the first maternal generation of ancestors two different formulas are needed to quantify the completeness of the four lineages:

$$
\begin{aligned}
& C_{\text {pat.m/mat.f }}=\frac{1}{d} \cdot \sum_{i=1}^{d} a_{i} \\
& C_{\text {pat. } f / \text { mat.m }}=\frac{1}{d-1} \cdot \sum_{i=1}^{d} a_{i}
\end{aligned}
$$

where is $d$ the number of generations of ancestors and $a_{i}$ the portion of known ancestors in the $i$-th generation.

The importance of all ancestors as contributors to the average inbreeding of the current population was analysed by calculating their relative fraction of the mean of the population's inbreeding.

For the development of a population, the rate of inbreeding is substantial. It means the population's increase of inbreeding per generation or the increase of the population's average coefficient of inbreeding per generation. For this parameter, the so-called effective size of a population $\left(N_{e}\right)$ is decisive, that is the number of individuals of an »ideal population « (population with random mating and equal sex distribution) which is equivalent to the actual population. The effective size of a population $N_{e}$ results from:

$$
N_{e}=\frac{4 \cdot N_{m} \cdot N_{f}}{N_{m}+N_{f}}
$$

where is $N_{m}$ the number of breeding males and $N_{f}$ the number of breeding females of the population. The relationship between the effective size $N_{e}$ of a panmictic population and the expected rate of inbreeding $\Delta F$ is as follows:

$$
\Delta F=\frac{1}{2 \cdot N_{e}}
$$


The rate of inbreeding for preceding generations has been estimated by the following formulas:

$$
\Delta F_{1}=\frac{F_{t}}{n-1}
$$

where is $\Delta F_{1}$ the mean rate of inbreeding in all generations of ancestors included and $F_{t}$ the mean coefficient of inbreeding of the current generation. $\Delta F_{1 c}$ is the mean rate of inbreeding in all generations of ancestors included, based on coefficients of inbreeding corrected by coefficients of completeness.

$$
\Delta F_{2}=\frac{F_{t}-F_{t-1}}{1-F_{t-1}}
$$

where is $\Delta F_{2}$ the rate of inbreeding in the last generation, $F_{t}$ the mean coefficient of the current generation, and $F_{t-1}$ the mean coefficient of inbreeding of the parental generation. $\Delta F_{2 c}$ represents the rate of inbreeding in the last generation, based upon the coefficients of inbreeding corrected by the coefficients of completeness.

\section{Results}

\section{Generation intervals}

The generation intervals between parents and individuals of the current generation amounts to about seven years, the value of the males being about 1.4 years higher than that of the females (Table 1).

Table 1

Mean generation intervals and their ranges (years)

Durchschnittliche Generationsintervalle und deren Schwankungsbreite (Jahre)

\begin{tabular}{lllllll}
\hline Path & \multicolumn{2}{c}{ Population } & \multicolumn{2}{c}{ Females } & & \multicolumn{2}{c}{ Males } \\
\hline Parents - offspring & 6.96 & $(2.46-11.46)$ & 6.50 & $(2.46-10.86)$ & 7.94 & $(5.32-11.08)$ \\
Fathers - offspring & 6.56 & $(2.31-11.21)$ & 5.86 & $(2.31-10.01)$ & 8.10 & $(6.40-11.21)$ \\
Mothers - offspring & 7.36 & $(2.61-11.71)$ & 7.14 & $(2.61-11.71)$ & 7.78 & $(4.23-10.94)$ \\
\hline
\end{tabular}

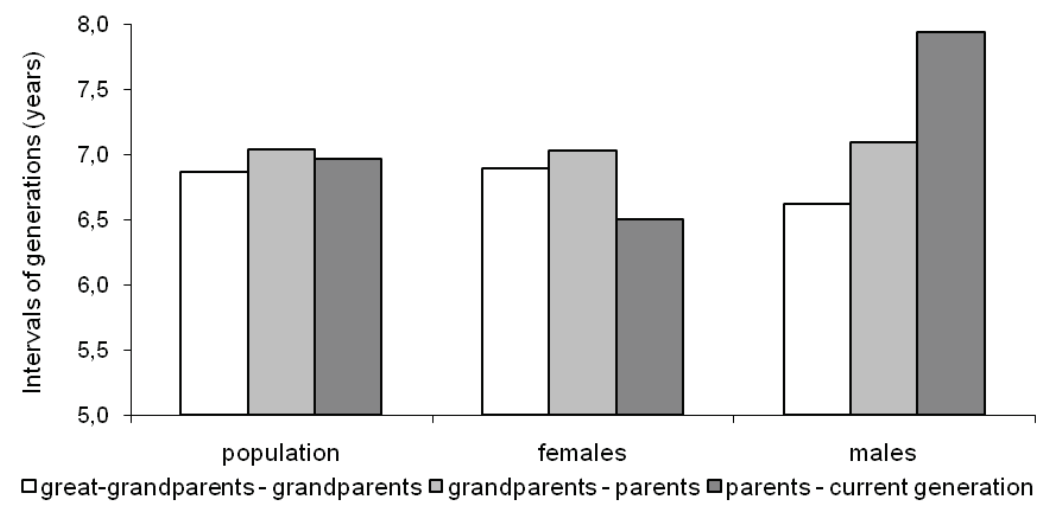

Figure 2

Course of mean intervals of generations during successive generations

Entwicklung der mittleren Generationsintervalle im Verlauf der Generationen 
Figure 2 shows that the generation intervals within the total population and the female population varied more or less in the course of preceding generations. The intervals of generation of the male population, however, has consistently increased.

\section{Genetic relationships within the population}

The average coefficient of coancestry within the population is approximately $18 \%$. It is less between the females but much higher between the males (Table 2). The maximum is $87.50 \%$. About $42 \%$ of all the cases within the population (nearly $50 \%$ within the females but only $18 \%$ within the males) are without any relationship.

Table 2

Coefficients of coancestry (above) and their distribution (below, \%) Verwandtschaftskoeffizienten (oben) und deren Verteilung (unten, \%)

\begin{tabular}{lccc}
\hline & Population & Females & Males \\
\hline Mean coefficient of relationship $\overline{\mathrm{R}}, \%$ & 18.19 & 15.75 & 25.09 \\
Maximum coefficient of relationship $\mathrm{R}_{\max } \%$ & 87.50 & 87.50 & 78.13 \\
Mean index of completeness, \% & 53.48 & 49.23 & 66.76 \\
$\mathrm{R}=0$ & 41.65 & 49.43 & 18.18 \\
$0<\mathrm{R} \leq 10$ & 4.86 & 4.92 & 1.82 \\
$10<\mathrm{R} \leq 20$ & 11.84 & 9.09 & 20.00 \\
$20<\mathrm{R} \leq 30$ & 16.17 & 14.39 & 23.64 \\
$30<\mathrm{R} \leq 40$ & 9.83 & 8.14 & 18.18 \\
$40<\mathrm{R} \leq 50$ & 8.03 & 7.20 & 12.73 \\
$50<\mathrm{R} \leq 60$ & 3.17 & 2.84 & 0.00 \\
$60<\mathrm{R} \leq 70$ & 2.64 & 2.65 & 1.82 \\
$70<\mathrm{R} \leq 80$ & 1.37 & 0.95 & 3.64 \\
$80<\mathrm{R} \leq 90$ & 0.42 & 0.38 & 0.00 \\
\hline
\end{tabular}

\section{Coefficients of inbreeding}

The average coefficient of inbreeding $\overline{\mathrm{F}}$ in the total population equals approximately $9 \%$. Within the male population it is nearly $10 \%$. The maximum value is $37.50 \%$ (Table 3 ). After correction by the indices of completeness the corrected coefficient of inbreeding $\bar{F}_{c}$ increases to about $16-17 \%$. Yet more than $40 \%$ of all animals are not inbred.

\section{Animals contributing to inbreeding}

In Table 4 animals contributing to inbreeding specified with their number of ties causing the inbreeding of the actual population and their contribution to the average inbreeding of the population are listed. The sire Hestehave Ursus stands out as a very important contributor to inbreeding. More than $40 \%$ of inbreeding inherent in the population can be traced back to this ancestor. Other significant contributors to inbreeding are the sires Nelson, Gerhard, Chartley, and Quartermaster, and the cows Sally and Tempelson Violet.

\section{Rate of inbreeding}

During the preceding three generations the increase of inbreeding $\Delta \mathrm{F}_{1}$ of the total population amounted to $4.62 \%$, within the females to $4.50 \%$, and within the males to $4.97 \%$ (Table 5). Considering the index of completeness the values changed to much higher levels $\left(\Delta \mathrm{F}_{1 c}\right)$. The rate of inbreeding increased within the total population and within 
the female population to nearly $8 \%$, and to nearly $9 \%$ within the male population. The rate of inbreeding $\Delta \mathrm{F}_{2}$ between the generation of parents and the current generation is higher than that between the means of all former generations of ancestors, but after having performed the correction by indices of completeness of the pedigrees the rate of inbreeding leaps up to a very high level of $11-12 \%\left(\Delta \mathrm{F}_{2 c}\right)$.

Table 3

Degrees of inbreeding (above) and their distribution (below, \%)

Inzuchtkoeffizienten (oben) und deren Verteilung (unten, \%)

\begin{tabular}{lccr}
\hline & Population & Females & Males \\
\hline Mean coefficient of inbreeding $\overline{\mathrm{F}}, \%$ & 9.23 & 9.00 & 9.94 \\
Maximum coefficient of inbreeding $\mathrm{F}_{\text {max },} \%$ & 37.50 & 37.50 & 28.13 \\
Mean index of completeness $\overline{\mathrm{C}}$, \% & 57.96 & 58.21 & 57.20 \\
Corrected mean coefficient of inbreeding $\overline{\mathrm{F}}_{\mathrm{C}}, \%$ & 15.93 & 15.46 & 17.38 \\
$\mathrm{~F}=0$ & 43.18 & 42.42 & 45.45 \\
$0<\mathrm{F} \leq 5$ & 2.27 & 3.03 & 0.00 \\
$5<\mathrm{F} \leq 10$ & 22.73 & 24.24 & 18.18 \\
$10<\mathrm{F} \leq 15$ & 4.55 & 6.06 & 0.00 \\
$15<\mathrm{F} \leq 20$ & 9.09 & 9.09 & 9.09 \\
$20<\mathrm{F} \leq 25$ & 6.82 & 3.03 & 18.18 \\
$25<\mathrm{F} \leq 30$ & 6.82 & 6.06 & 9.09 \\
$30<\mathrm{F} \leq 35$ & 2.27 & 3.03 & 0.00 \\
$35<\mathrm{F} \leq 40$ & 2.27 & 3.03 & 0.00 \\
\hline
\end{tabular}

Table 4

Animals contributing substantially to inbreeding

Inzuchtverursacher

\begin{tabular}{lcccc}
\hline Name & Sex & Born & Number of ties & $\begin{array}{c}\text { Contribution to } \\
\text { mean inbreeding, \% }\end{array}$ \\
\hline Population & male & 1989 & 22 & 43.85 \\
Hestehave Ursus & male & unknown & 9 & 15.39 \\
Nelson & female & 1994 & 3 & 12.31 \\
Sally & male & 2000 & 2 & 12.31 \\
Gerhard & male & unknown & 9 & 8.46 \\
Chartley Quartermaster & female & 1988 & 6 & 7.69 \\
Tempelson Violet & & & & \\
Females & male & 1989 & 17 & 42.11 \\
Hestehave Ursus & male & unknown & 7 & 16.84 \\
Nelson & female & 1994 & 3 & 16.84 \\
Sally & female & 1988 & 5 & 8.42 \\
Tempelson Violet & male & 2000 & 1 & 8.42 \\
Gerhard & male & unknown & 6 & 7.37 \\
Chartley Quartermaster & & & & \\
Males & male & 1989 & 6 & 49.49 \\
Hestehave Ursus & male & 2000 & 1 & 21.99 \\
Gerhard & male & unknown & 4 & 11.34 \\
Chartley Quartermaster & male & unknown & 2 & 11.00 \\
Nelson & female & 1988 & 1 & 5.50 \\
Tempelson Violet & male & unknown & 1 & 0.69 \\
Dynevor Claudius & & & \\
\hline
\end{tabular}


Table 5

Rate of inbreeding, \%

Inzuchtraten, \%

\begin{tabular}{lrrrrrr}
\hline & \multicolumn{2}{c}{ Population } & \multicolumn{2}{c}{ Female } & \multicolumn{2}{c}{ Male } \\
& $\Delta \mathrm{F}$ & \multicolumn{1}{c}{$\mathrm{N}_{\mathrm{e}}$} & \multicolumn{1}{c}{$\Delta \mathrm{F}$} & \multicolumn{1}{c}{$\mathrm{N}_{\mathrm{e}}$} & \multicolumn{1}{c}{$\Delta \mathrm{F}$} & \multicolumn{1}{c}{$\mathrm{N}_{\mathrm{e}}$} \\
\hline$\Delta \mathrm{F}_{1}$ & 4.62 & 10.83 & 4.50 & 11.12 & 4.97 & 10.06 \\
$\Delta \mathrm{F}_{1 \mathrm{c}}$ & 7.97 & 6.28 & 7.73 & 6.47 & 8.69 & 5.75 \\
$\Delta \mathrm{F}_{2}$ & 7.12 & 7.02 & 7.34 & 6.81 & 7.04 & 7.10 \\
$\Delta \mathrm{F}_{2 \mathrm{c}}$ & 11.17 & 4.48 & 11.78 & 4.25 & 12.05 & 4.15 \\
\hline
\end{tabular}

\section{Discussion}

Only three generations of ancestors could be included into the present analysis because the pedigrees of many animals are incomplete. Moreover, the date of birth of many ancestors is unknown. This prevents their inclusion in the calculation of generation intervals. These inherent insufficiencies have to be considered when drawing conclusions from the analysis.

\section{Generation intervals}

The intervals of generations between male and female populations must be considered separately. Within dairy and beef breeds the bulls are rather young when they are recruited for mating or artificial insemination. In the case of White Park Cattle, however, sires begin mating at a different age. Therefore, the generation interval of the male line is not as important in contrast to that of the female line. In order to realize high breeding progress within efficiently bred populations, short generation intervals are advantageous. Within small populations with the main aim of conservation, long generation intervals are advantageous in order to minimize the increase of inbreeding per unit of time, as shown in the following equation:

$$
\Delta F / \text { year }=\frac{\Delta F / \text { generation }}{G l}
$$

where is $\Delta F /$ year the rate of inbreeding per year, $\Delta F /$ generation the rate of inbreeding per generation, and $G /$ the generation interval (years).

In the present investigation the generation intervals between mothers and their offspring appear rather favourable (7.4/7.1/7.8 years). From this equation, it is clear, that in order to effect a further increase, it would be preferable to select the later born female offspring for breeding.

Comparisons with breeds under stringent economically motivated selection as dairy breeds are not recommendable. Other breeds, where conservation of the population is the top target like the Hinterwald Cattle with 6.5 years (BIEDERMANN et al. 2003), exhibit lower values.

\section{Coefficients of coancestry}

More than $58 \%$ of all White Park Cattle in the German population are related with each other to varying degrees. The maximum value of coancestry amounts to almost $88 \%$. 
The observed coefficient of coancestry is higher than those reported for other cattle breeds. Here are examples of coefficients of coancestry in other breeds: Brown Cattle in Baden-Württemberg: 2\% (BOLLMEIER et al. 1991), Hinterwald Cattle: 2\% (BIEDERMANN et al. 2003), Vorderwald Cattle: 3.6\% (BIEDERMANN et al. 2004), German Black Pied Lowland Breed: $4.5 \%$ (BIEDERMANN et al. 2005).

In all these investigations, population size was typically small and high coefficients of coancestry were expected. Accordingly, ROUGHSEDGE et al. (1999) estimated a mean coefficient of coancestry to be only $1.3 \%$ in the considerably large population of British Holstein-Friesian. Nevertheless, high mean coefficients of coancestry can be common also in large populations, as it is the case with the population of Holsteins of the United States of America for which YOUNG and SEYKORA (1996) give the tremendously high value of $10.2 \%$. Such populations are characterized by the use of a limited number of sires for artificial insemination.

\section{Inbreeding and main contributors}

Due to the possibility of inbreeding depression and increased frequency of recessive homozygotes for deleterious alleles, inbreeding is a great concern.

The mean values of inbreeding found in cattle populations mostly range from $0.3 \%$ to 1.7\% (HAGGER 1988: Swiss Brown Cattle, MIGLIOR et al. 1990, 1995: Canadian Jerseys and Holsteins, BOLLMEIER et al. 1991: Brown Cattle of Baden-Württemberg, SCHMIDT 1993: Westphalian Dapple Reds, NAVAJAS and URIOSTE 1995: Aberdeen-Angus of Argentina, YOUNG and SEYKORA 1996: US-American Holsteins, KROGMEIER et al. 1997: Gelbvieh and Brown Cattle of South Germany, ROUGHSEDGE et al. 1999: British Holstein-Friesians; BIEDERMANN et al. 2003: Hinterwald Cattle). Even rather high values of inbreeding estimated for Vorderwald Cattle (2.3\%, BIEDERMANN et al. 2004), American Holsteins and Jerseys (approximately 5\%, CASSEL et al. 2000a,b) are less than the coefficient of inbreeding calculated for the White Park Cattle.

Following the statements of JOHANNSON and LUSH (1957), inbreeding does matter if the coefficient of inbreeding exceeds $6.25 \%$. This value, surpassed considerably by the White Parks, shows that they are unparalleled among domestic cattle. Moreover, it has to be considered that historically they have been intensively inbred over many generations. Certainly it can be supposed that the mean inbreeding as well as the mean relationship of them are much higher than indicated by means of only three generations of ancestors. To what extent inbreeding results in depression and threatens a population, is the topic of investigations mostly concerning foreign cattle populations (THOMPSON et al. 2000a, b, BIFFANl et al. 2002, CARAVIELLO et al. 2003, CASSEL et al. 2003a, b, UZMAY and AKBAS 2003). It was shown that inbreeding causes depression in all traits which are important for dairy breeding, such as constitution, fertility, and duration of use, which are the traits characterized by a low heritability. But in all these investigations, however, depressions are not of dramatic dimensions in consequence of rather moderate inbreeding. According to the statements of SUJET et al. (2001) reproduction traits will be considerably affected only in cases where inbreeding values exceed $12 \%$.

In the literature, the importance of recessive hereditary defects is seldom mentioned. Nevertheless it is important to take them into account. GENTILE et al. (2002) report the 
frequent occurrence of spastic paresis within the rather small population of Romagnola Cattle in north Italy. They assume that the prevalence of this disease is the result of unavoidably intensive inbreeding.

The key question is, how was the White Park Cattle able to survive up to now without visible defects although they have been intensively inbred over a very long time. Only ALDERSON (2008) mentions that modern White Park Cattle are smaller than their ancient ancestors. This fact is detected by skeletons found in the Chillingham-Park. Certainly it can be expected, that losses of certain alleles caused by inbreeding, have happened during the long history of the breed. Conversely inbreeding can effectively eliminate undesired genes in a population. PIRCHNER (1979) mentions that long periods of inbreeding can lead to resistance against further inbreeding by selectively eliminating deleterious genes. Perhaps White Park Cattle embody an example for such a process.

Finally it is necessary to focus attention on the fact that only a few ancestors in Germany are responsible for the majority of inbreeding within the population. Additionally these ancestors are more or less related to each other, as is documented by their pedigree.

\section{Rate of inbreeding}

The effective population size and the rate of inbreeding are of great importance for the future development of a population. They are considered the decisive measures for estimation of the degree of endangerment within a population. High rates of inbreeding and a small effective population size, respectively, are linked to a progressive loss of genetic variability and decrease the potential for future breeding. Concerning the long-term conservation of a population, the German Society of Animal Breeding (Deutsche Gesellschaft für Züchtungskunde, DGfZ) (1992) recommended that the effective size of population $\mathrm{N}_{\mathrm{e}}$ should not fall below a value of 50 equivalent to a rate of inbreeding of $\Delta \mathrm{F}=1 \%$. Nevertheless BREM et al. (1990) state that even this value induces an extensive renunciation of selection and successful breeding. In order to realize a successful selection they recommend a minimal effective population size of $100(\Delta \mathrm{F}=0.5 \%)$. For the White Park Cattle however, this aspect is not relevant because there is no economic need to improve the breed. In 2004 the Federal Ministry of Consumer Protection, Nourishment and Agriculture (BMVEL) published a »National Program for the Conservation and Enduring Use of Genetic Resources«. In this publication, populations with $\mathrm{N}_{\mathrm{e}} \leq 0.50$ and $\Delta \mathrm{F} \geq 1.0 \%$, respectively, are termed as "phenotypic populations of conservation «, meaning populations which possess a durable maintenance.

In the light of these recommendations, the German White Park population has to be regarded as highly endangered, because the estimated rate of increase in inbreeding exceeds all above mentioned criteria.

In most cattle populations the rate of inbreeding is significantly lower, for example Murnau-Werdenfels Cattle (GRAML et al. 1988), Brown Cattle of Württemberg (BOLLMEIER et al. 1991), Westphalian Dapple Reds (SCHMIDT 1993), Canadian Holsteins (MIGLIOR et al. 1990, 1995), Gelbvieh and Brown Cattle (KROGMEIER et al. 1997), Belgian Blues (HANSET et al. 2002), Bavarian Simmentals and Tyrol Grays (PIRCHNER 2002), and Hinterwald and Vorderwald Cattle (BIEDERMANN et al. 2002, 2003). Only for the German Black Pied Lowland Breed BIEDERMANN et al. (2005) estimated a comparatively high rate of increase of inbreeding of $1.4 \%$, which is still lower than the values found for White Park Cattle. 


\section{Conclusions}

The average coefficient of coancestry in the investigated German White Park Cattle has been estimated to be $18 \%$ and the average degree of inbreeding to be $16 \%$. Thus, the White Park Cattle represent a unique phenomenon in the history of animal breeding. The fact that the breed still exists in spite of considerable inbreeding can only be explained by the rigorous natural selection to which it was subjected during all the centuries. Therefore, an extensively stable resistance against inbreeding may have appeared. Nevertheless it seems appropriate to choose breeding animals in a way that minimizes the rate of increase of inbreeding to an unavoidable extent, especially by mating animals related as distantly as possible. For this reason, a careful choice of sires is necessary.

\section{References}

Alderson GLH (2008) White Park Cattle. http://www.whiteparkcattle.org.uk/history.html [last accessed 30.09.2009]

Ancient White Park Cattle Society of North America (2008). White Park. http://www.ansi.okstate.edu/ breeds/cattle/whitepark/index.htm [last accessed 30.09.2009]

Anonymus (2008) White Park Cattle. http://wikipedia.org/wiki/White Park Cattle [last accessed 30.09.2009]

Biedermann G, Ott B, Rübesam K, Maus F (2004) Genetic analysis of the population of Vorderwald Cattle. Arch Tierz 47, 141-53 [in German]

Biedermann G, Waldmann S, Maus F (2003). Genetic analysis of the population of Hinterwald Cattle. Arch Tierz 46, 307-19 [in German]

Biedermann G, Poppinga O, Weitemeyer I (2005) The genetic structure of the population of the Black Pied Lowland Breed. Züchtungskunde 77, 3-14 [in German]

Biffani S, Samore AB, Canadesi F (2002) Inbreeding depression for production, reproduction and functional traits in Italian Holstein cattle. Proceedings of the 7th World Congress on Genetics applied to Livestock Production, Montpellier, Session 9, 1-4

BMVEL (2004) Genetic resources of animals - National specialist program [in German]

Bollmeier S, Mayer M, Simon D (1991) Development of the genetic structure of Württemberg Brown Cattle. Züchtungsk 63, 1-11 [in German]

Brem G, Brening B, Müller M, Springmann K, Kräusslich H (1990) Genetic diversity of the cattle breeds. Eugen Ulmer, Stuttgart, Germany [in German]

Caraviello DZ, Weigel KA, Gianola D (2003) Analysis of the relationship between type traits, inbreeding, and functional survival in Jersey cattle using a Weibull proportional hazards model. J Dairy Sci 86, 2984-9

Cassel BG, Adamec V, Pearson RE (2003a) Effect of incomplete pedigrees on estimates of inbreeding and inbreeding depression for days to first service and summit milk yield in Holsteins and Jerseys. J Dairy Sci 86, 2967-76

Cassel BG, Adamec V, Pearson RE (2003b) Maternal and fetal inbreeding depression for 70-day nonreturn and calving rate in Holsteins and Jerseys. J Dairy Sci 86, 2977-83

Chillingham Wild Cattle Association (2008) The Wild White Cattle of Chillingham. http://www.whiteparkcattle.org.uk/chillingham.htm [last accessed 30.09.2009]

DGfZ (1992) Recommendations for the conservation of living animal stocks of native endangered livestock breeds. Züchtungsk 62, 77-80 [in German]

Gentile A, Pittoni S, Bergamini PF (2002) Spastic Paresis in Romagnola cattle. Atti Soc It Buiatria 34, 191-8

Graml R, Lang G, Schmid DO, Wittkowski G, Krause I, Buchberger J, Pirchner F (1988) Inbreeding increment and effective population size of Murnau-Werdenfelser and German Fleckvieh estimated from marker gene frequencies. Züchtungsk 60, 288-99 [in German]

Hagger C (1988) Level of inbreeding in Swiss Brown Cattle. Landwirtsch Schweiz 1, 293-296 [in German]

Hanset RS, Tilesse DE, Michaux P, Tillesse SDE (2002) Rate of inbreeding and effective size in the Belgian blue cattle breed. Proceedings of the 7th World Congress on Genetics applied to Livestock Production, Montpellier, Session 26, 1-3

Johansson I, Lush JL (1959) Methods of breeding and selection. In: Hammond J, Johannsson I, Haring F (Ed.) Handbook of animal breeding, vol. 2 Population genetics. Paul Parey, Hamburg and Berlin [in German] 
Krogmeier D, Aumann J, Averdunk G (1997) Inbreeding in German Gelbvieh and German Braunvieh. Züchtungsk 69, 233-43 [in German]

Miglior F, Burnside EB (1995) Inbreeding of Canadian Holstein cattle. J Dairy Sci 78, 1163-7

Miglior F, Burnside EB, Sullivan BP, Szkotnicki B, Kennedy BW (1990) Trends in inbreeding in Canadian dairy cattle. Proc. 4th World Congress on Genetics applied to Livestock Production, Edinburgh, 183-6

Navajas EA, Urioste JI (1995) Effects of inbreeding and preweaning growth of Aberdeen-Angus calves. Rev Arg Prod Anim 15, 880-3

Pirchner F (1979) Population genetics in animal breeding. Paul Parey, Hamburg und Berlin [in German]

Pirchner $F$ (2002) Estimation of the effective population size by means of variations of gene frequencies in Bavarian Simmentals and Tyrol Grauvieh. Arch Tierz 45, 331-9 [in German]

Roughsedge T, Brotherstone S, Visscher PM, Boyazoglou J, Rafal P, Thomas C, Zjalic M (1999) Quantifying genetic contributions to a dairy population using pedigree analysis. EAAP Publication 60, 359-69

Schmidt T (2000) OPTI-MATE 3.3 - Manual of a management program for minimizing inbreeding in endangered populations [in German]

Schmidt T (1993) Analysis of inbreeding, relationship, generation interval and breeding progress in the population of Westpalian Dapple Reds. Diss Bonn [in German]

Sujit S, Avtar S, Joshi BK, Saha S, Singh A (2001) Incidence, level and consequences of inbreeding in cattle a review. Indian J Dairy Sci 54, 59-69

TGRDEU (Zentrale Dokumentation Tiergenetischer Ressourcen in Deutschland) (2001) List of native breeds and their classification relative to their endangerment. http://tgrdeu.genres.de/ [last accessed 30.09.2009]

Thompson JR, Everett RW, Wolfe CW (2000a) Effects of inbreeding on production and survival in Jerseys. J Dairy Sci 83, 2131-8

Thompson JR, Everett RW, Hammerschmidt NL (2000b) Effects of inbreeding on production and survival in Holsteins. J Dairy Sci 83, 1856-64

Uzmay C, Akbas Y (2003) The level of inbreeding and its effect on milk yield, age at first calving and calf mortality in Holstein cattle reared on the Faculty farm of Ege University. Turk Vet Hayv Derg 27, 935-41

Wrede J, Schmidt T (2004) OPTI-MATE 3.38. Management program for minimizing inbreeding in endangered populations [in German]

Young CW, Seykora AJ (1996) Estimates of inbreeding and relationship among registered Holstein females in the United States. J Dairy Sci 79, 502-5

Received 16 August 2009, accepted 30 September 2009.

Corresponding author:

Prof. Dr. GÜNTER BIEDERMANN

email: gue.bie@t-online.de

Schützenstraße 18, 37213 Witzenhausen, Germany 